\title{
Is our vaccine supply secure?
}

\author{
M lan Bowmer MD FRCPC
}

S ecurity has become the watchword since September 11, 2001. We talk of securing borders and securing air travel safety, and the federal government even titled its 2001 budget, Securing Progress in an Uncertain World (1). Like my colleagues in academic medicine, I was delighted with the steps that the government started to take in its 'strategic investments' to increase funding for research and research infrastructure. The question that has not had meaningful public discussion, however, surrounds Canada's ability to secure and provide its population with appropriate pharmaceuticals and biological protection in the face of current demand, which includes the threat of bioterrorism. When the government attempted to secure Cipro (Bayer, Canada) for anthrax treatment, we experienced a taste of the problems that can arise. On this occasion, it became an argument only about the appropriate supplier, and not about whether there was sufficient supply or which population, which country, would have priority for the product.

Vaccine production and supply are very different issues. We have already had supply problems with some of the currently produced vaccines, including those for influenza and meningococcus. How will Canada respond to the new terrorism of anthrax and the threatened one of smallpox if large numbers of people need to be vaccinated?

In 1980, the World Health Organization declared, "Smallpox is dead!" (2). In their 1985 review, Oxford and Oberg (3) noted that smallpox vaccine production was so relatively uncontrolled and standardized that it would not likely be licensed if it were proposed as a new vaccine today. The amount of smallpox vaccine that is stored in Canada and the United States is inadequate for our populations, and although dilution of the vaccine has been proposed, we have no experience with such an approach in a mass vaccination program. In December, Health Canada's Centre for Emergency Preparedness issued a request for information about companies that are able to produce smallpox vaccine.
Replies were to be submitted by January 7, 2002. This request underscores the national storage centre's inability to produce an adequate supply of the vaccine.

This is ironic, given that the formation of Canada's Department of Health was a result of the recognition that Public Health could not be only a Provincial responsibility and through the leadership of people who were involved in establishing the Antitoxin Vaccine Laboratories at the University of Toronto. In 1913, Dr John FitzGerald returned to Toronto from his travels in Europe with a definite plan to establish a laboratory that could produce antitoxin and vaccines. Support came from a strong public health activist in the Ontario Public Health Department, Dr JWS McCullough, and from the University of Toronto's Dr J Amyot. They recognized the positive impact that free biological products such as diphtheria antitoxin could have on poor people's health and on the economy of the province. It was the First World War, however, that created the demand for tetanus antitoxin and smallpox vaccine production. In 1915, Colonel Gooderham donated the farmland that enabled the University of Toronto Antitoxin Laboratory, in collaboration with the Canadian Red Cross, to expand its production facilities. Gooderham decided to name the site after the Governor General of the day, the Duke of Connaught. The dramatic impact of public health measures, and vaccine and antitoxin protection during World War I, the recognition that this was a national public issue, and the impact of the 1918 influenza epidemic combined to persuade the Canadian government to establish the Department of Health in 1918, with Dr Amyot as its first deputy minister (4).

Canada now faces the possibility of another type of biological threat, and the question is "can we respond?". Production facilities have merged and are now international corporate operations that are not necessarily responsive to Canadian needs. We have already experienced some sup- 
ply difficulties with specific vaccines (eg, meningococcus) and the United States has had problems with its influenza vaccine supply. As we face new threats, we must ask the critical questions: Is Canada's vaccine acquisition stable? Is our production ability secure? Are pharmaceutical industry laboratories sufficient, or should we be housing vaccine development and production capability within publicly funded institutions? Can a national laboratory, linked with a research institution and/or a university not only perform the research and development function, but also become the production unit in times of supply shortages?

Canada must take notice of the actions that have been taken in this area in the United States. The Bioterrorism Preparedness Act (5) allocates US\$2.6 billion for biological preparedness! Included in this amount is more than half a billion American dollars for the purchase and deployment of a smallpox vaccine, US $\$ 165$ million for the Centers for Disease Control and Prevention to upgrade its capacity, and nearly US\$600 million for pharmaceutical stockpiling.
Developing a publicly funded vaccine production capacity would clearly be a shift in current policy, and it requires significant debate. Because we have no secure supply for some regularly used vaccines, and because there is no publicly funded production mechanism for emergency vaccines, this debate is urgent.

\section{REFERENCES}

1. Securing Progress in an Uncertain World: Budget 2001. Department of Finance, Canada.

2. World Health Organization. The Global Eradication of Smallpox: Final report of the Global Commission for the Certification of Smallpox Eradication. World Health Organization: Geneva, 1979.

3. Oxford JS, Oberg B. Conquest of Viral Diseases. A Topical Review of Drugs and Vaccines. New York: Elsevier, 1985.

4. Bator PA, Rhodes AJ. Within Reach of Everyone: A History of the University of Toronto School of Hygiene and the Connaught Laboratories, Volume 1, 1927-1955. Ottawa: Canadian Public Health Association, 1990.

5. Association of American Medical Colleges. Senate approves biological agents provision; House passes bioterrorism bill. Washington Highlights 2001;12:45.

This article also appears in Paediatr Child Health 2002;7:67-68 


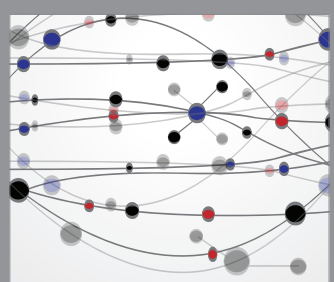

The Scientific World Journal
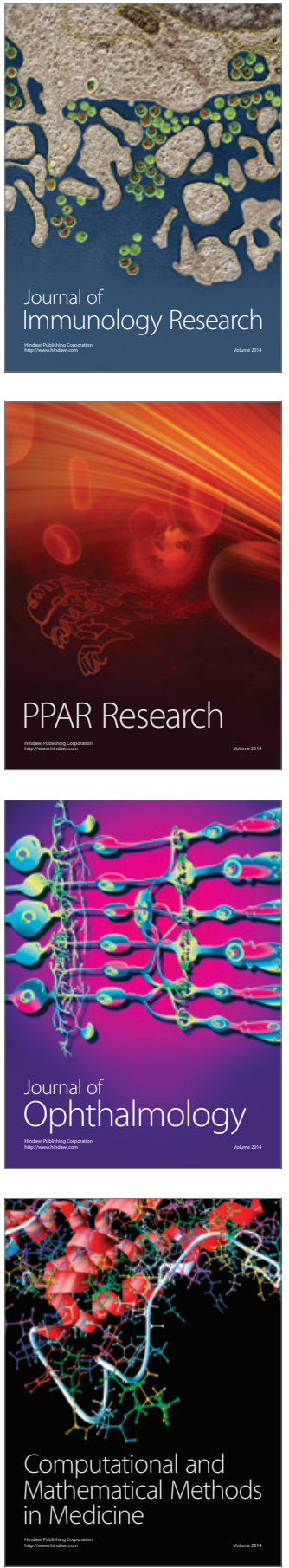

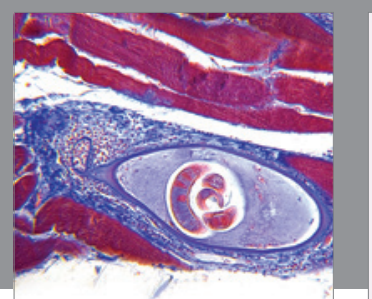

Gastroenterology Research and Practice

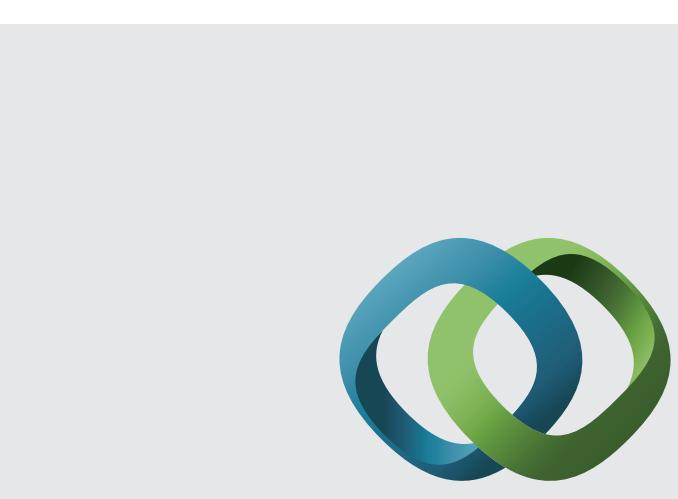

\section{Hindawi}

Submit your manuscripts at

http://www.hindawi.com
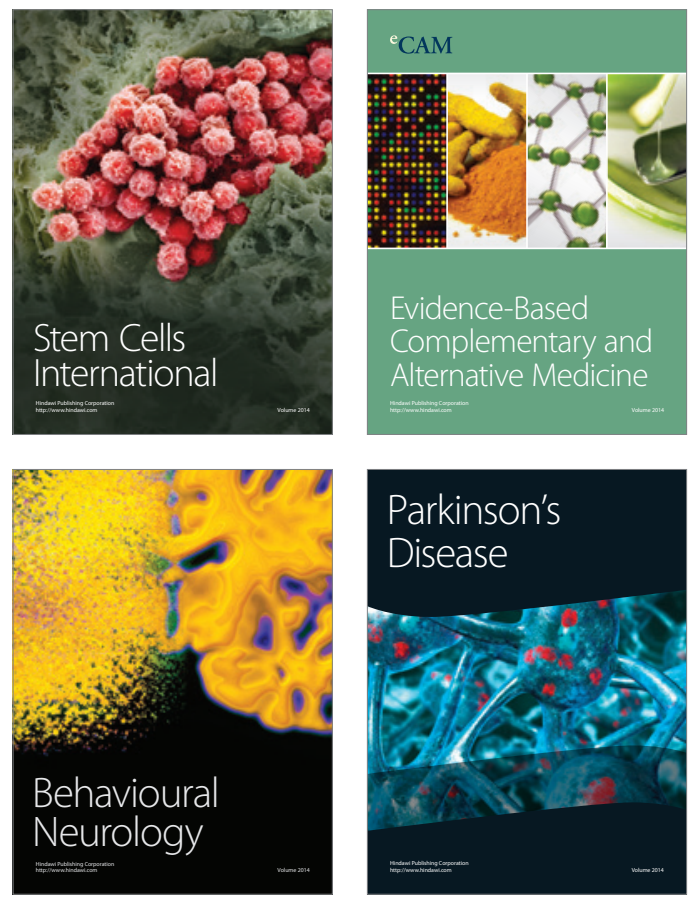
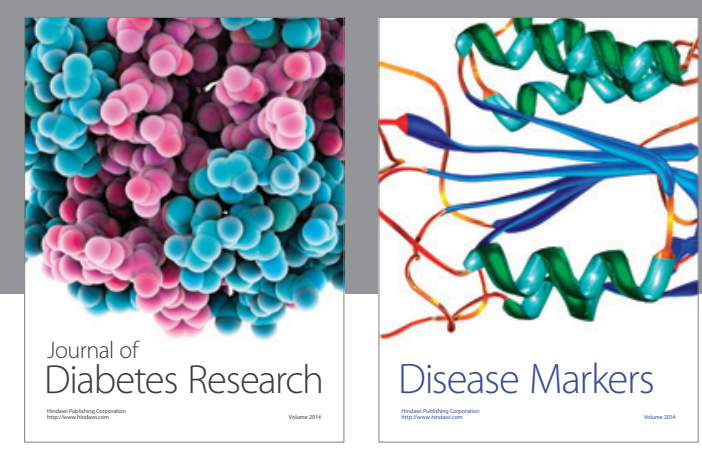

Disease Markers
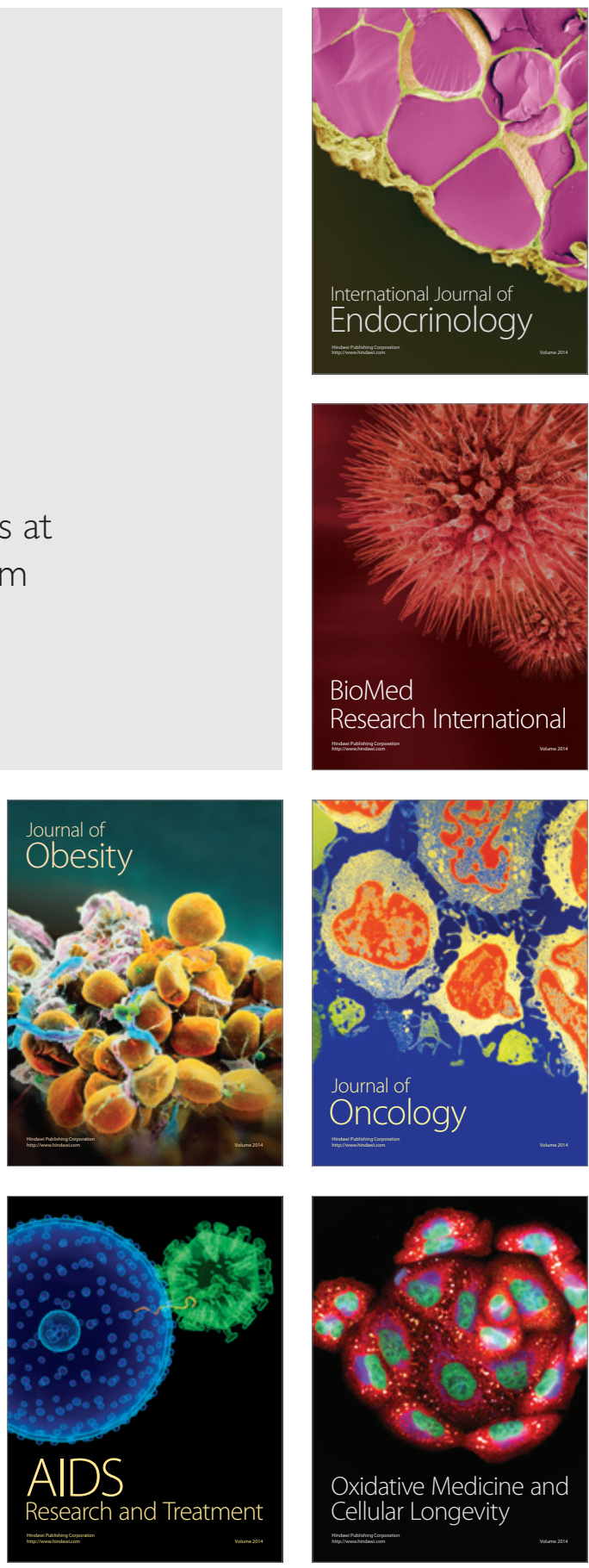